\title{
ST14 Gene
}

National Cancer Institute

\section{Source}

National Cancer Institute. ST14 Gene. NCI Thesaurus. Code C26586.

This gene is involved in the activation of proteases and latent growth factors in epithelial membranes. 